\title{
Investigation of Mean Platelet Volume, Platelet Distribution Width and Erythrocyte Distribution Width in Patients with Hepatitis B Virus Infection
}

\author{
Hepatit B Virüs Enfeksiyonu Bulunan Kișilerde Ortalama Trombosit Hacmi, Trombosit \\ Dağılım Genișliğinin ve Eritrosit Dağılım Genișliğinin Araștıııması
}

\author{
Kazım KIRATLI1 , Erdem ÇEVIK² \\ ${ }^{1}$ Katip Çelebi University, Atatürk Training and Research Hospital, Clinic of Infectious Diseases and Clinical Microbiology, Izmir, Turkey \\ 2 University of Health Sciences, Haydarpaşa Sultan Abdülhamid Training and Research Hospital, Clinic of Emergency Medicine, Istanbul, Turkey
}

\begin{abstract}
Objective: Hepatitis B virus (HBV) infection is an important public health issue all over the world, and it has a high morbidity and mortality rates caused by chronic liver disease. Liver biopsy is the primary procedure for evaluating the fibrosis grade. Recently, noninvasive methods are used to predict liver histology. Complete blood count $(\mathrm{CBC})$ is one of the most needed and used laboratory tests in clinics. CBC parameters have been used in various studies to estimate the severity of the disease and the risk of mortality. In the present study, we aimed to determine the relationship of HBV infection with mean platelet volume (MPV), platelet distribution width (PDW) and red cell distribution width (RDW).

Materials and Methods: Two hundred fifty-nine hepatitis B surface antigen (HBsAg)-positive patients, who attended the Infectious Diseases outpatient Clinic at Van Military Hospital between October 2013 and December 2014, were included in the study group. A total of 245 food handlers with similar socio-demographic characteristics with the study group, who applied at the same period, formed the control group. HBsAg-positive patients were studied in two groups as chronic active hepatitis and inactive carriers according to their follow-up. CBC results of the patients and the healthy controls were screened from the hospital information system and they were evaluated retrospectively.

Results: The average platelet count in HBsAg-positive patients and controls was $262.59 \pm 62.13 \times 103 / \mathrm{mm}^{3}$ and $245.28 \pm 60.78 \times 103 / \mathrm{mm}^{3}$, respectively and the difference between the groups was statistically significant $(p=0.002)$. There was also statistically significant difference in RDW values between the two groups. The average RDW was $12.14 \pm 1.05$ in HBV group, while it was $12.49 \pm 1.28$ in control group ( $\mathrm{p}=0.001)$. On the other hand, no significant difference was observed in PDW and MPV between the groups.
\end{abstract}

\section{$0 ̈ Z$}

Amaç: Hepatit B virüs (HBV) enfeksiyonu tüm dünyada önemli bir halk sağlığı sorunudur ve kronik karaciğer hastalığına bağlı yüksek bir morbidite ve mortalite oranına sahiptir. Karaciğer biyopsisi, fibrozisin derecesini belirlemek için primer yöntemdir. Son zamanlarda, karaciğer histolojisini öngörmek için non-invaziv yöntemler kullanılmaktadır. Tam kan sayımı, kliniklerde en çok intiyaç duyulan ve kullanılan laboratuvar testlerinden biridir. Tam kan sayımı parametreleri, hastalığın ciddiyetini ve mortalite riskini belirlemek için çeşitli çalışmalarda kullanıımıştır. Bu çalışmada HBV enfeksiyonu ile ortalama trombosit hacmi (MPV), trombosit dağılım genişliği (PDW) ve eritrosit dağılım genişliği (RDW) parametreleri arasındaki ilişkiyi saptamayı amaçladık.

Gereç ve Yöntemler: Ekim 2013-Aralık 2014 tarihleri arasında Van Asker Hastanesi Enfeksiyon Hastalıkları Polikliniği'ne, hepatit B yüzey antijeni (HBsAg) pozitifliği nedeni ile başvuran 259 hasta, araştırmamızda çalışma grubunu oluşturdu. Aynı tarihlerde polikliniğine başvuran, çalışma grubu ile benzer sosyo-demografik özelliklere sahip 245 gıda elleyicisi de kontrol grubunu oluşturdu. HBsAg pozitif hastalar, izlemlerine göre kronik hepatit ve inaktif taşıyıcılar olmak üzere iki grupta incelendi. Hastaların ve sağlıklı grubun tam kan sayımı sonuçları, hastane bilgi sisteminden tarandı ve retrospektif olarak değerlendirildi.

Bulgular: HBsAg pozitif hastalarda trombosit ortalaması $245,28 \pm 60,78 \times 103 / \mathrm{mm}^{3}$, kontrol grubunda $262,59 \pm 62,13 \times 103 /$ $\mathrm{mm}^{3}$ tü ve bu gruplar arasındaki fark istatistiksel olarak anlamlıydı $(p=0,002)$. Iki grup arasındaki RDW değerleri de istatistiksel olarak anlamlı bir farklılık gösterdi. HBV grubunda RDW ortalaması $12,14 \pm 1,05$, kontrol grubunda ise $12,49 \pm 1,28^{\prime} d i \quad(p=0,001$ ). Öte yandan, PDW ve MPV ile ilgili gruplar arasında anlamlı bir fark gözlenmedi. 


\section{ABSTRACT}

Conclusion: It is thought that simple, inexpensive and routinely used platelet and erythrocyte parameters in combination with other inflammatory parameters may help predict liver inflammation. While platelets and RDW are decreased in people with HBV infection, MPV and PDW are not changed. We assume that platelets and RDW should be evaluated together in HBsAgpositive patients, and further studies with larger samples should be performed.

Keywords: Hepatitis B, chronic liver disease, mean platelet volume, erythrocyte distribution width
ÖZ

Sonuç: Basit, ucuz ve rutinde sıklıkla kullanılan trombosit ve eritrosit parametrelerinin, diğer enflamatuvar parametreler ile birlikte karaciğer enflamasyonunu öngörmede yardımcı olabileceği düşünülmektedir. HBV enfeksiyonu olan kişilerde trombosit ve RDW azalırken, MPV'nin ve PDW'nin değişmediği gözlendi. HBsAg pozitif hastalarda trombosit ve RDW'nin birlikte değerlendirilmesini, ayrıca bu konu ile ilgili çalışmaların daha geniş gruplarda devam etmesi gerektiğini düșünmekteyiz.

Anahtar Kelimeler: Hepatit B, kronik karaciğer hastalığı, ortalama trombosit hacmi, eritrosit dağılım genişliği

Kıratlı K, Çevik E. Investigation of Mean Platelet Volume, Platelet Distribution Width and Erythrocyte Distribution Width in Patients with Hepatitis B Virus Infection. Viral Hepat J. 2017;23:60-63.

\section{Introduction}

Hepatitis B virus (HBV) infection is an important public health issue all over the world, and it has a high morbidity and mortality rates caused by chronic liver disease (1). Countries with a HBV carrier rate of less than $2 \%$ of are considered low endemic, those with between $2 \%$ and $10 \%$, moderate, and those with $>10 \%$ are considered high endemic regions. Although there are regional differences in Turkey, the seroprevalence of hepatitis $B$ surface antigen ( $\mathrm{HBsAg}$ ) is between $3.9 \%$ and $12.5 \%$ and we are considered to be in the moderate endemic region (2).

Liver biopsy is the primary procedure for evaluating the fibrosis stage (3). However, the method is expensive and its invasive nature limits its use in some cases due to complications and contraindications (4). For this reason, non-invasive parameters are used to predict liver histology $(5,6,7,8)$.

Inactive HBV carriers constitute the majority of chronic hepatitis $B$ cases and they have a low risk of hepatocellular carcinoma (HCC) or cirrhosis (9). Therefore, close follow-up for inactive carriers is important in terms of development of liver cirrhosis and HCC. The relatively low risk of HCC limits the usage of invasive methods such as biopsy. Consequently, the use of non-invasive methods is important to determine the level of inflammation and chronicity in inactive HBV carriers (10).

Mean platelet volume (MPV) and platelet distribution width (PDW) are some parameters in complete blood count (CBC), which define thrombocyte size and the extent of diversity in thrombocyte size (4). MPV is also a marker of inflammation and its severity (11).

Red cell distribution width (RDW) is an automatic measurement of the variability of the red blood cell size. It is used in predicting the cause of anemia (12). New studies have declared that elevation of RDW values is associated with high mortality risk in different patient groups (13).

$\mathrm{CBC}$ is one of the most needed and used laboratory tests in clinics. CBC parameters have been used in various studies to estimate the severity of the disease and the risk of mortality. In the present study, we aimed to determine the relationship between HBV infection and MPV, PDW and RDW parameters.

\section{Materials and Methods}

In our study, 259 HBsAg positive patients, who attended the infectious diseases outpatient clinics at Van Military Hospital between October 2013 and December 2014, were included in the study. A total of 245 food handlers with similar socio-demographic characteristics with the study group, who applied at the same period formed the control group. Serum HBsAg and anti-HBc lgG titres were analysed using the enzyme-linked immunosorbent assay (ELISA) method by Beckman Coulter Access 2 (Beckman Coulter, FL, USA). CBC (platelet and erythrocyte indices) was performed by LH780 Beckman Coulter (Beckman Coulter, FL, USA).

The HBsAg positive patients were studied in two groups as chronic hepatitis and inactive carriers according to their follow-up. $\mathrm{CBC}$ results of the patients and the healthy controls were screened from the hospital information system and they were evaluated retrospectively. There was no additional disease in HBsAg positive patients (e.g. diabetes mellitus, ischemic heart disease, thyroid disease, etc.).

We used SPSS version 16.0 to perform statistical procedures. All continuous variables were expressed as mean \pm standard deviation. Student's t-test was used for comparison of independent quantitative data showing normal distribution. One-Way analysis of variance (ANOVA) was used for comparison between independent subgroups. Categorical data were evaluated by the chi-square test. Data were evaluated at $95 \%$ confidence interval and a $p$ value of less than 0.05 was considered statistically significant. This research was approved by the Gülhane Military Medical Faculty's Ethics Committee (12.01.2015/50687469-1491-28-14/1648.4-66).

\section{Results}

The average platelet count in HBsAg-positive patients and controls was $245.28 \pm 6078 \times 10^{3} / \mathrm{mm}^{3}$ (79-444) and $262.59 \pm 62.13 \times 10^{3} / \mathrm{mm}^{3}$, respectively (85-595), and the difference between the groups was statistically significant $(p=0.002)$. There was a statistically significant difference also in RDW values between the two groups. The average RDW in HBV group and 
control group was $12.14 \pm 1.05$ and $12.49 \pm 1.28$, respectively $(p=0.001)$. However, no significant difference was observed in PDW and MPV between the groups (Table 1).

When we divided HBsAg positive subjects into chronic infection and inactive carriers groups, there was no significant difference between the groups, but we found a significant difference in platelet count between chronic infection group and the healthy group $(p=0.009)$. In addition, RDW values showed significant difference between the inactive carrier group and the healthy group ( $p=0.003$ ) (Table 2 ). On the other hand, there was no significant difference in MPV and PDW values between the groups.

\section{Discussion}

HBV infection is a common disease worldwide, with a prevalence of over $8 \%$ in some regions, especially in Southeast Asia, Sub-Saharan Africa and Central America. It is estimated that 2 billion people worldwide are suffering from this infection and 350 million of them are carriers or chronically infected (14). HBV infection may appear in a wide range of spectrum between asymptomatic carriage and fulminant hepatitis requiring liver transplantation as well. Liver cirrhosis and HCC may develop later in patients who are followed up for chronic hepatitis in this process (15).

Platelets have an important role in the pathogenesis of local and systemic inflammation-related disorders. Thrombotic and inflammatory agents released from platelets can trigger disease-specific complications. Platelets are also closely associated with hemostasis, inflammation, immune cell activation, tissue regeneration and other physiological and pathological processes (16). It has been reported that MPV increased in patients with essential hypertension, hypothyroidism, obesity, coronary heart disease, and diabetes and in smokers (1).

$\mathrm{RDW}$ is an index showing the distribution of the sizes of circulating erythrocytes in CBC. RDW is used in the diagnosis of anemia and its elevation is observed in hemolysis and erythrocyte production disorders. RDW does not only increase in hematologic diseases, but also increases in pulmonary embolism, acute renal failure, pulmonary arterial hypertension, peripheral arterial disease and stroke. Since RDW has been shown to be correlated with inflammatory markers such as CRP, it is now accepted as a marker of inflammation (17).
Turhan et al. (1) reported statistically higher MPV values in 260 inactive hepatitis B patients compared to controls in their study. In another study of 59 patients with chronic hepatitis B, increased MPV was found to be associated with advanced fibrosis. It has been suggested that MPV might be useful in assessing fibrosis in patients with chronic hepatitis B (18).

In a study by Karabulut and Namlı (19), significant high values were found in the PDW parameter in HBsAg positive subjects, but no significant difference was found in MPV between HBsAg positive patients and controls. However, Ceylan et al. (4) reported that low MPV values and high PDW values were associated with severe liver fibrosis in patients with hepatitis B. Uluca et al. (10) found no difference in MPV values between inactive HBV carriers and controls.

In a study by Demircan et al. (20), significantly elevated MPV levels were detected in patients with HCV infection which was thought to be due to the effect of the virus leading to platelet dysfunction. Hakyemez et al. (21) reported no association between PDW value and severe cirrhosis. However, the association of advanced liver fibrosis with RDW, PLT and MPV was statistically significant in chronic hepatitis B cases. They declared that plateletderived indices may play a critical role in monitoring liver fibrosis and cirrhosis progression. Karagoz et al. (13) found significantly high MPV and RDW values in HBV infected patients, and they declared that these parameters could be used in determining liver damage. In our study, there was no difference between the groups in terms of MPV and PDW values.

In a study by Lou et al. (12), high RDW values were reported to be associated with disease severity in hepatitis B patients. Therefore, this difference is an important factor affecting the progression of the disease and is considered an important marker in patients with HBV infection. In a recent study, RDW was found to be higher in HBV related cirrhotic patients than in chronic hepatitis B cases and healthy subjects (22).

In the present study, the average platelet count in HBsAgpositive patients and controls was $245.28 \pm 60.78 \times 10^{3} / \mathrm{mm}^{3}$ and $262.59 \pm 62.13 \times 10^{3} / \mathrm{mm}^{3}$, respectively and there was a statistically significant difference between the groups as expected. The average RDW was $12.14 \pm 1.05$ in HBV infected group, while it was $12.49 \pm 1.28$ in control group. This difference was observed between the HBV carriers and the controls. In contrast to many studies, lower RDW values were detected in hepatitis B cases.

Table 1. Relationship between hepatitis B surface antigen positive patients and healthy group

\begin{tabular}{|l|l|l|}
\hline Parameter & HBsAg (+) patients & Healthy group \\
\hline Platelet x 1000 (K/uL) & $245.28 \pm 60.78$ & $262.59 \pm 62.13$ \\
\hline Mean platelet volume (fL) & $8.64 \pm 4.29$ & 0.002 \\
\hline Platelet distribution width (\%) & $12.14 \pm 2.7$ & $8.54 \pm 1.03$ \\
\hline Erythrocyte distribution width (\%) & $12.14 \pm 1.05$ & $12.02 \pm 4.06$ \\
\hline HBsAg: Hepatitis B surface antigen & $12.49 \pm 1.28$ \\
\hline
\end{tabular}

Table 2. Relationship between inactive carrier, chronic infection and healthy group

\begin{tabular}{|c|c|c|c|c|}
\hline Parameter & Inactive carrier & Chronic infection & Healthy group & $p$ \\
\hline Platelet x 1000 (K/uL) & $247.97 \pm 55.30$ & $241.75 \pm 67.40^{*}$ & $262.59 \pm 62.13^{*}$ & $0.009 *$ \\
\hline Erythrocyte distribution width (\%) & $12.08 \pm 1.0 * *$ & $12.23 \pm 1.11$ & $12.49 \pm 1.28 * *$ & $0.003^{* *}$ \\
\hline
\end{tabular}




\section{Conclusion}

It is envisaged that simple, inexpensive and also routinely used platelet and erythrocyte parameters in combination with other inflammatory parameters may help predict liver inflammation. While platelet count and RDW decreased in people with HBV infection, MPV and PDW did not change. We assume that platelets and RDW should be evaluated together in HBsAg positive patients, and further studies on this subject should be continued in larger groups.

\section{Ethics}

Ethics Committee Approval: This research was approved by the Gülhane Military Medical Faculty's Ethics Committee (12.01.2015/50687469-1491-28-14/1648.4-66).

Informed Consent: The Declaration of Helsinki and Good Clinical Practice Guidelines were respected during the entire process of enrolling the patients in the study and collecting/ analyzing/reporting the data.

Peer-review: Internally peer-reviewed.

\section{Authorship Contributions}

Concept: K.K., Design: K.K., Data Collection or Processing: K.K., E.Ç., Analysis or Interpretation: E.Ç., K.K., Literature Search: K.K., Writing: K.K.

Conflict of Interest: No conflict of interest was declared by the authors.

Financial Disclosure: The authors declared that this study received no financial support.

\section{References}

1. Turhan O, Coban E, Inan D, Yalcin AN. Increased mean platelet volume in chronic hepatitis B patients with inactive disease. Med Sci Monit. 2010;16:202-205.

2. Bilgiç A, Özacar T. Hepatit B Virüsü. Içinde: Topçu AW, Söyletir G, Doğanay M. Infeksiyon Hastalıkları ve Mikrobiyolojisi, 2. Baskı, Istanbul: Nobel Tıp Kitapevleri; 2002; s. 1350-1370.

3. Liaw YF, Leung N, Kao JH, Piratvisuth T, Gane E, Han KH, Guan R, Lau GK, Locarnini S. Chronic Hepatitis B Guideline Working Party of the Asian-Pacific Association for the Study of the Liver. AsianPacific consensus statement on the management of chronic hepatitis B: a 2008 update. Hepatol Int. 2008;2:263-283.

4. Ceylan B, Mete B, Fincanci M, Aslan T, Akkoyunlu Y, Ozguneş N, Colak O, Gunduz A, Senates E, Ozaras R, Inci A, Tabak F. A new model using platelet indices to predict liver fibrosis in patients with chronic hepatitis B infection. Wien Klin Wochenschr. 2013;125:453-460.

5. Koda M, Matunaga Y, Kawakami M, Kishimoto Y, Suou T, Murawaki Y. Fibroindex, a practical index for predicting significant fibrosis in patients with chronic hepatitis C. Hepatology. 2007;45:297-306.

6. Rossi E, Adams L, Prins A, Bulsara M, de Boer B, Garas G, MacQuillan G, Speers D, Jeffrey G. Validation of the fibrotest biochemical markers score in assessing liver fibrosis in hepatitis C patients. Clin Chem. 2003:49:450-454.
7. Adams LA, Bulsara M, Rossi E, DeBoer B, Speers D, George J, Kench J, Farrell G, McCaughan GW, Jeffrey GP. Hepascore: an accurate validated predictor of liver fibrosis in chronic hepatitis $\mathrm{C}$ infection. Clin Chem. 2005;51:1867-1873.

8. Wai CT, Greenson JK, Fontana RJ, Kalbfleisch JD, Marrero JA, Conjeevaram HS, Lok AS. A simple noninvasive index can predict both significant fibrosis and cirrhosis in patients with chronic hepatitis C. Hepatology. 2003;38:518-526.

9. Yilmaz B, Aydin H, Can G, Şentürk Z, Üstüner B, Yilmaz $H$, Öztürkler M, Roach EC, Korkmaz U, Kurt M, Çelebi A, Şentürk Ö, Hülagü $S$. The relationship between fibrosis level and blood neutrophil to lymphocyte ratio in inactive hepatitis B carriers. Eur J Gastroenterol Hepatol. 2014;26:1325-1328.

10. Uluca U, Sen V, Gunes A, Tan I, Aktar F, Cubuk E, Sabaz MN. Inaktif Hepatit B Tașıyıcılarında Nötrofil Lenfosit Oranı ve Ortalama Trombosit Hacminin Değerlendirilmesi, Mustafa Kemal Üniversitesi Tıp Dergisi. 2015;6:8-13.

11. Gasparyan AY, Ayvazyan L, Mikhailidis DP, Kitas GD. Mean platelet volume: a link between thrombosis and inflammation? Curr Pharm Des. 2011;17:47-58.

12. Lou $Y$, Wang $M$, Mao W. Clinical usefulness of measuring red blood cell distribution width in patients with hepatitis B. PLoS One. 2012;7:e37644.

13. Karagoz E, Ulcay A, Tanoglu A, Kara M, Turhan V, Erdem H, Oncul $\mathrm{O}$, Gorenek L. Clinical usefulness of mean platelet volume and red blood cell distribution width to platelet ratio for predicting the severity of hepatic fibrosis in chronic hepatitis B virus patients. Eur J Gastroenterol Hepatol. 2014;26:1320-1324.

14. Ağca H. Hepatit B Serolojisi. Altındiş M, Tabak F. Hepatit Mikrobiyolojisi,1.Baskı, Istanbul: Istanbul Medikal Yayıncılık; 2015; s. 76-82.

15. De Paschale M, Ceriani C, Cerulli T, Caqnin D, Cavallari S, Ndayake J, Zaongo D, Priuli G, Vigano P, Clerici P. Prevalence of HBV, HDV, $\mathrm{HCV}$, and HIV Infection During Pregnancy in Northern Benin. J Med Virol. 2014;86:1281-1287.

16. Tanju C, Ekrem G, Berksoy Emel A, Nur A. Mean platelet volume as a negative marker of inflammation in children with rotavirus gastroenteritis. Iran J Pediatr. 2014;24:617-622.

17. Karakaş MF, Büyükkaya E, Kurt M, Büyükkaya S, Karakaș E, Akçay $A B$, Şen N. Kardiyak Sendrom X'de Eritrosit Dağılım Genişliği (RDW) ile Hs-CRP Seviyelerinin Incelenmesi. Abant Med J. 2013;2:17-22.

18. Ekiz F, Yüksel O, Koçak E, Yılmaz B, Altınbaş A, Çoban S, Yüksel I, Üsküdar O, Köklü S. Mean platelet volume as a fibrosis marker in patients with chronic hepatitis B. J Clin Lab Anal. 2011;25:162165.

19. Karabulut N, Namlı MN. HBsAg pozitif hastaların trombosit indekslerinin değerlendirilmesi. ANKEM Derg. 2015;29:73-78.

20. Demircan F, Kılınç F, Gözel N, Şenateş BE, Şenateş E. The Evaluation of Mean Platelet Volume in Hepatitis C Infection, Viral Hepat J. 2014;20:11-14.

21. Hakyemez IN, Bolukçu S, Durdu B, Aslan T. Red Cell Volume Distribution Width to Platelet Ratio is an Important Predictor of Liver Fibrosis and Cirrhosis in Chronic Hepatitis B. Viral Hepat J. 2016:22:52-57. 